\title{
Taking Qingdao as an Example of Development and Design of Regional Tourism Souvenirs
}

\author{
Jian Zhao ${ }^{1, ~ a, ~ L i a n g ~ Z h a n g ~}{ }^{1, b}$ and Linan Zheng ${ }^{1, c}$ \\ ${ }^{1}$ Mechanical and electrical Engineering College, Qingdao Binhai University, Shandong, China \\ a84310626@qq.com, b76201691@qq.com, ${ }^{\mathrm{c}} 1021090387 @ q q . c o m$
}

Keywords: Regional; Travel; Features; Souvenirs; Development and design

\begin{abstract}
By inherited tradition of Qingdao local culture, modern culture and tourism culture studied, summarized their traditions, characteristics and forms of modern tourism culture, combined with the local traditional culture, modern cultural integration of cultural resources for tourism and cultural souvenirs were analyzed and summarized, Qingdao souvenirs combining traditional culture and modern culture improved integrated design. Under the "hospitality Shandong" tourism brand environment, tourism souvenir design ideas refining, integration of traditional design elements and modern design elements, Tour design elements, design and development with a strong flavor of Qingdao tourist souvenirs.
\end{abstract}

\section{Introduction}

Qingdao is one of the famous seaside resort and China's outstanding tourist city, mountain and sea, beautiful scenery and pleasant weather. Red, green trees, blue sea, blue sky and a cross-matched Qingdao beautiful figure; red reef, small waves, painted sails, golden beaches constitute Qingdao beautiful landscape; history, religion, folklore, customs, festivals gives Qingdao Tourism rich cultural connotations. Modern history and culture concentrated Celebrities; countries with typical European-style architecture, the formation of Chinese and Western characteristics [1]. Qingdao is the National Garden City, China Excellent Tourism City, the international coastal tourist resort of Qingdao in 2014 received a total of 66 million passengers and foreign tourists, and showed a rising trend. With the rapid development of tourism and tourist spending habits change, China's tourism development is shifting from the state to the unique sightseeing tourism, leisure, vacation forms coexist trend. For tourists always want to buy souvenirs with local characteristics, but now a lot of souvenirs stereotyped, less variety, nothing special, the lack of local, not attractive to tourists, visitors and even boring. Tourism Bureau survey in 2014 shows that the average per domestic and foreign tourists in the area shopping spend only 1.61 yuan, while travel to the United States mainland tourists shopping spending amounted to only US \$987, tourists to Europe as much as the average shopping 1781 dollars, highest in the world [2]. Therefore, the development of tourism souvenirs design has become to attract those who travel for shopping, tourism to stimulate consumption, to promote its image of the city of Qingdao, Qingdao raise international awareness of the determinants.

\section{The Main Method of Modern Design and Development of Tourist Souvenirs}

Qingdao characteristics of cultural tourism souvenir development and design can learn from the following:

Contains geographical and cultural connotations. A large proportion of the traditional tourist souvenirs handicraft souvenir, often associated with a particular cultural traditions and customs together, so it is with people's daily habits closer, but also implies humanistic value, easily accepted by people, but based on personal experience and traditional crafts-based, with great closed and conservative[3]. In any commodity production, the needs of the community decided to design and produce what souvenirs, diverse needs of the community and the development of resistance, grasp these needs, we will build the social, economic and cultural progress of organic combination, in condenses among the physical form of souvenirs. 
Pay attention to artistic creation. Tourism souvenir design, a certain sense, is the combination of technology and art, that is, it should on the basis of compliance with the law on science and technology play an expressive aesthetic function and form of material souvenirs. As mentioned earlier, people's needs are evolving, souvenirs in the form of development is never enough, and therefore does not create the ultimate aesthetic and end. The German Bauhaus school first president of Georgia Luopi ust once said, is the product of the real tradition to continue moving forward, his essence is in motion, not static, tradition should push people to continue moving forward. Create aesthetic souvenirs to adhere to the principle of development to meet the interesting people to pursue change and freshness requirements.

Play a role in modeling language. Language is a product of convention, so in the use of modeling language to take into account cultural backgrounds and differences in consumer objects exist; Aesthetic Images should have compatibility, to adapt to different personality and temperament and taste, so the artistic expression a certain ambiguity in order to achieve greater environmental adaptability[4]. In addition to the design process to reflect the most representative tourist and cultural characteristics, but also reflect certain values, to develop to meet the different consumers, different cultural level and aesthetic level of demand for souvenirs, broaden the consumer market; vividness Images performance modeling is unique, it can form a unique personality, does not result in itself submerged in the sea of similar souvenirs; souvenirs should have a sense of the times as far as possible, adapted to people's values and lifestyle changes.

With the times. Times based on contemporary standards of science and technology and cultural awareness as a background, reflecting the values and characteristics of contemporary culture, the spirit of the times and adapt in order to spur the development of lifestyle. For example, there is a long history of Tianjin "clay figurine Zhang" is often used as a colorful Tianjin unique souvenirs, but has been observed, "clay figurine Zhang" has been roughly in the shape of vintage theme[5]."Clay figurine Zhang" workers, if still not functioning as creators, but also serve as a designer, in the tradition of old themes, old technology, while design some vivid scenes of life figures present era, creating having a form of modern, will certainly be more loved by the people, especially young people, to further expand consumer groups. As souvenirs, even the traditional classic handicrafts, entirely immutable is not desirable, continuously into the modern elements, innovation, and they will have lasting vitality; various modeling elements also have the same tone or consistency of style, help unique souvenirs for people to understand language, geographical and cultural reach consensus, thereby facilitating the overall promotion of the region to achieve the purpose of cultural and geographical features.

Unified planning, establish brand awareness. Have brand awareness, to have a unified planning, all kinds of souvenirs should try to reflect a unified style, full of major cultural characteristics of the region, to facilitate the tourists the impression of consensus, but also easy unique in the numerous tourist attractions, and promote their individuality Tourism value; modeling should also reflect the advanced technology, that it is built on the technical basis of modern science [6].

\section{Qingdao Major Tourist Souvenirs Development and Design Strategies}

Qingdao characteristics and culture of division and re-adjusted to give, to break the existing division of economic, administrative areas, several areas have the same cultural characteristics of tourism, which is classified as a class, its combination of local tourism and cultural characteristics of traditional culture modern culture, tourism and cultural integration of design, planning for the following five main themes:

Building cultural theme tourist souvenirs. Badaguan villas, Chrysostom way, Laiyang Road, Yushan, signal Road, Qixia Road, Fuk Road, elephant road, a view of the sea, residential buildings Road neighborhood. Chinese and Western courtyard architecture. Colorful small buildings. Sleek and artistic treatment of Qingdao Qingdao small architectural appearance of the city and adds grace to learn from many cities[7]. Depending on the Qingdao construction culture design exquisite, tasteful, flexible architectural culture memorabilia.

Celebrity cultural theme tourist souvenirs. Kang Yu-wei, Lao She, Hong Shen and Wen, Shen, 
Wang Tong, Liang Shih-chiu, Wang Xian Tang House carries two, thirties period of literary history, can tap the cultural connotation deeper level, the development of tourism resources, the formation of tourist souvenirs[8].

Marine cultural theme tourist souvenirs. Through the creation of colorful marine life, learn to add ancient and modern artifacts, through scientific and technological strength to create science education tourism and cultural souvenirs. Expand the influence of Qingdao marine life, and increase its visibility and promote its all-round display in Qingdao marine culture, marine science and technology [9].

Religious and cultural theme tourist souvenirs. Religious tourism including religious believers because of the need for religious purposes culture memorabilia, including non-believers out of interest, aimed at study, experience or watch religious and cultural connotation of religious art, artifacts, shrines and other tourist and cultural souvenirs. The Temple of use Nam, the Catholic Church, the Christian church, temple, Laoshan Taoist temples and then jointly develop the East-West cultural religious souvenirs.

Cultural festival theme souvenirs. Festivals are regional culture and customs of the most concentrated expression, it is an important force for economic prosperity, promote urban and regional development. As an important carrier Qingdao travel every year to host or co-host of colorful festivals, major festivals such as China Qingdao Ocean Festival, China Qingdao International Beer Festival, Qingdao bar culture festival, Qingdao Cherry Blossom, The Temple temple, etc., have been It has aroused strong repercussions at home and abroad, and the country has become renowned Qingdao festival souvenirs. Since 1999, held each year in mid-July, it is currently China's only marine-themed festival. Festivals around the theme of the sea through marine science and technology economy in international forums, marine cultural activities, sports events, sea food and shopping, trade talks, the exciting tourism activities into showcase Qingdao Ocean Culture Characteristics of festival tourism brand in the country already has certain visibility[10]. China Qingdao International Beer Festival. It began in 1991, held annually in late August. Festivals in Qingdao century-old Tsingtao beer and international reputation as the core, a number of activities of tourism, culture, economy and trade, science and technology, and sports as a whole, the celebration color rich, distinctive beer culture, has developed into a relatively mature popularity, international of festivals. Qingdao Cherry Blossom. Zhongshan Park cherry blossoms on the renowned liberation activities, every year between April and May, a large cherry fiery clouds, Fei Yan a few years, Qingdao sites known as one of the "East Garden flowers." Qingdao will be the cherry annual spring outing Tour event in Zhongshan Park View cherry as the main content, and exhibitions and a variety of cultural and recreational activities.

\section{Conclusions}

The problem with traditional culture and modern culture, tourism and culture as the background, Qingdao characteristics of cultural tourism souvenirs re-integration of design, more innovative than the study of previous issues, the whole Qingdao Tourism and Culture re-division, breaking the original geographical division, when the same characteristics of tourism and cultural divide to become one, the tourism culture and traditional culture and modern culture combined with a variety of topics and highlighting the distinctive characteristics of the use of the design, linguistics, communication, consumer psychology, social science and other interdisciplinary theory as a guide, and proposed countermeasures Qingdao characteristics of cultural development, so that the characteristics of Qingdao culture from a single diversified marine culture, brand culture conducive to the spread of agglutination strength, promote the development of tourism economy through tourism souvenir design also publicized the development of tourism and cultural industries to drive.

\section{References}

[1] Dawson Munjeri. Tangible and Intangible Heritage: From Difference to Convergence [J]. Museum International, 2004, 56(1). 
[2] Shuming Liang. Chinese Culture [M]. Shanghai Century Publishing Group, People's Publishing House, 2012.3.(In China)

[3] Qiu Weili.Tourism souvenir design in the traditional sense of local cultural elements [J]. packaging engineering, 2012.10. (In China)

[4] Fuguang Zhang, Wang Guang. Souvenirs emotional interaction design aesthetics technology research [J]Aesthetics Technology,2013 (In China)

[5] Christian M. Rogerson. Conference and Exhibition Tourism in the Developing World: The South African Experience [J]. Urban Forum, 2005,9

[6] Xingyi Bai. Tourism souvenir design based on regional culture connotation [J]. China Packaging,2012.05.33 (20):109-112 (In China)

[7] Ting Zhang. Design of souvenirs Inner [D]. Mongolia Normal University. Inner Mongolia. China (In China)

[8] M Gray. Geodiversity: The origin and evolution of a paradigm. Geological Society, London, Special Publications, 2008, 300: 31-36.

[9] A C Mathis. Communicating geoheritage values with the public. 2005 Salt Lake City Annual Meeting of GSA/Geological Society of America Abstracts with Programs, 2005, 37(7):190.

[10]Getz, D. Meeting Business. Encyclopedia of Tourism[M].New York: Routleledge, 2000,P:387 